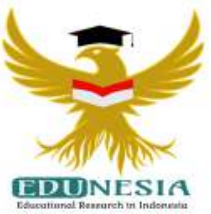

\title{
Pengaruh Multimedia Interaktif Pada Pembelajaran Biologi Jaringan Tumbuhan Terhadap Keaktifan Dan Pengetahuan Siswa SMAN 6 Darul Makmur
}

\author{
Rita Oktavia \\ Pendidikan Biologi STKIP Bina Bangsa Meulaboh,Indonesia \\ Corresponding Email: ritaoktavia87@gmail.com, Phone Number : 0853 xxxx xxxx
}

\section{Article History:}

Received: Agust 06, 2020

Revised: Agust 24, 2020

Accepted: Agust 24, 2020

Published: Nov 01, 2020

Keywords:

Activity, Interactive

Multimedia, Knowledge, Plant tissue.

Kata Kunci:

Jaringan Tumbuhan, Keaktifan, Multimedia Interaktif, Pengetahuan

\section{How to cite:}

Oktavia, R. (2020). Pengaruh Multimedia Interaktif Pada Pembelajaran Jaringan Biologi Tumbuhan Terhadap Keaktifan Dan Pengetahuan Siswa SMAN 6 Darul Makmur. Edunesia : Jurnal Ilmiah Pendidikan, 1 (3): 73-81

This is an open access article under the $C C-B Y-N C-N D$ license
Abstract: The research objective was to determine the effect of interactive multimedia on plant tissue material on the activeness and student knowledge of class XI students of SMA Negeri 6 Darul Makmur. This type of research is a quasi-experimental quantitative research. The research design used a non-equivalent control group design. The study was conducted in September 2018. The population in this study consisted of class XI IPA1 of 20 students as the experimental class and XI IPA2 of 20 students as the control class. From the research results, it was found that the effect of interactive multimedia on plant tissue material on the activeness and knowledge of class XI students of SMA Negeri 6 Darul Makmur was significantly better than students who got the application of interactive multimedia (criteria for $t$ count $\leq$ $\mathrm{t}$ table). Based on thes result of the T-Test is indicated by the value of $\mathrm{t}$ $=0.83$, with $\mathrm{db}=40$ at the $5 \%$ significance level obtained $\mathrm{t}$ table $=0.005$. From the research results obtained, it can be concluded that interactive multimedia on plant tissue material affects the activeness and knowledge of class XI students of SMA Negeri 6 Darul Makmur

Abstrak: Tujuan penelitian adalah untuk mengetahui pengaruh multimedia interaktif pada materi jaringan tumbuhan terhadap keaktifan dan pengetahuan siswa kelas XI SMA Negeri 6 Darul Makmur. Menggunakan pendekatan kuantitatif, dengan jenis penelitian quasi eksperimen dengan disain Nonequivalent Control Group Design. Penelitian dilaksanakan pada bulan September 2018. Populasi dalam penelitian ini yang terdiri dari kelas XI IPA ${ }^{1}$ sebanyak 20 siswa sebagai kelas eksperimen dan XI IPA ${ }^{2}$ sebanyak 20 siswa sebagai kelas kontrol. Dari hasil penelitian ditemukan bahwa pengaruh multimedia interaktif pada materi jaringan tumbuhan terhadap keaktifan dan pengetahuan siswa kelas XI SMA Negeri 6 Darul Makmur secara signifikan lebih baik dari pada siswa yang mendapatkan penerapan multimedia interaktif (kriteria $t_{\text {hitung }} \leq t_{\text {tabel }}$ ). Hal ini ditunjukkan oleh nilai hasil Uji T-Test yaitu thitung $=0,83$, dengan $\mathrm{db}=40$ pada taraf signifikansi $5 \%$ diperoleh $t_{\text {tabel }}=0,005$. Dari hasil penelitian dapat disimpulkan bahwa pengaruh multimedia interaktif terhadap jaringan tumbuhan berpengaruh terhadap keaktifan dan pengetahuan siswa kelas XI SMA Negeri 6 Darul Makmur. 


\section{A. Pendahuluan}

Pembelajaran Biologi adalah pembelajaran yang berbasis pada pemahaman konsep dan keterlibatan langsung. Dalam pembelajaran Biologi khususnya jaringan Tumbuhan adalah sebuah materi yang tidak dapat dipahami hanya melaui penjelasan konsep dan pemahaman. Tetapi diperlukan media alternatif lain diantaranya praktikum langsung, penggunanna multimedia interaktif dan virtual laboratorium. Namun, pada kenyataannnya kompetensi guru Biologi belum memiliki kemahiran dibidang Teknologi dan belum menerapkan model pembelajaran Multimedia Interaktif. Ketrampilan Teknologi ini sangat lah penting bagi Guru dalam menggahadapi Era 4.0 pada saat sekarang ini. Karena dalam sebuah pembelajarana Biologi diperlukan adanya interaksi antara siswa dan guru, terutama dalam materi-materi bersifat abstrak yang sulit digambarkan. Diperlukan upaya yang lebih oleh guru untuk dapat menyampaikan materi dengan berbagai teknik model pembelajaran.

Mengamati hasil observasi peneliti dengan guru biologi yang melaksanakan pembelajaran dengan model konvensional memperlihatkan hasil bahwa peserta didik sulit memahami materi jaringan tumbuhan, siswa merasa bosan, materinya dirasakan rumit dan abstrak karena tidak bisa ditunjukan. Hal ini berdampak kepada keaktifan dan pengetahuan biologi siswa yang tergolong rendah. Maka sangat penting untuk melakukan kajian tentang pengaruh Multmedia Interaktif dalam pembelajaran Biologi.

Penggunaan Multimedia interaktif sangat penting dan sangat membantu dalam pembelajaran, selain dapat memaparkan materi yang berwarna, bergambar, bernimasi juga dapat menyertakan vidio auvisual. Menganalisis beberapa kajian yang telah membuktikan bahwa dengan penerapan multimedia interaktif diintegrasikan dengan model Inkuiri Terbimbing dapat meningkatkan berpikir kritis siswa SMA (Retnosari dkk., 2016). Telah dibuktikan juga terdapat perbedaan hasil belajar antara siswa yang menggunakan Multimedia Interaktif dengan Buku teks dalam pembelajaran Biologi di SMA(Kurniawan, 2019). Pemanfaatan multimedia interaktif pada pembelajaran Biologi terhadap motivasi dan kemampuan kognitif siswa SMP dibuktikan bahwa multimedia interaktif berpengaruh terhadap hasil belajar kognitif siswa SMP (Havis, 2018).

Beberapa pengembangan media pembelajaran biologi berbasis pengembangan multimedia interaktif diantaranya pengembangan multimedia interaktif pada materi sistem saraf pada siswa SMA yang dikemas dalam Compact Disc (CD) yang berisi tampilan teks, gambar, suara, animasi, vidio yang akan digunakan sebagai media pembelajaran biologi (Triyanti, 2015). Kajian multimedia pembelajaran pada materi kultur jaringan menggunakan Camtasia Studio 8 yang dikembangkan melalui tahapan analisis kebutuhan dan karakteristik siswa, desain produk yang dibuat menggunakan aplikasi CamtasiaStudio8 (Aulia \& Aina, 2016). Selain itu penelitian pengembangan dengan menghasilkan produk berupa media pembelajaran berbasisi android juga telah dikembangkan (Fatmala \& Yelianti, 2016).

Mengamati hasil penelitian relevan maka sangat penting untuk dilakukan penelitian tentang pengaruh multimedia interaktif terhadap keaktifan dan pengetahuan siswa kelas XI-IPA SMA Negeri 6 Darul Makmur. Selain itu, Kajian pembelajaran dengan penerapan Multimedia Interaktif belum banyak diterapkan di sekolah Kabupaten Nagan Raya, dan belum banyak hasil riset yang terpublikasi terkait Multimedia Interaktif berdasarkan hasil penelitian pendidikan Wilayah Barat Selatan Aceh. 
Rumusan permasalahan penelitian yaitu Apakah terdapat pengaruh multimedia interaktif pada materi jaringan tumbuhan terhadap keaktifan dan pengetahuan siswa kelas XI SMA Negeri 6 Darul Makmur.

Tujuan penelitian ini adalah Untuk mengetahui pengaruh multimedia interaktif pada materi jaringan tumbuhan terhadap keaktifan dan pengetahuan siswa kelas XI SMA Negeri 6 Darul Makmur.

\section{B. Metode}

Pendekatan yang digunakan dalam penelitian ini adalah pendekatan kuantitatif. Jenis penelitian ini menggunakan eksperimen quasi dengan desain yang non-ekuivalen. Penelitian dilakukan di SMAN 6 Darul Makmur Kabupaten Nagan Raya pada bulan juliseptember Tahun 2018. Populasi yang digunakan dalam penelitian ini adalah siswa kelas XI-IPA sebanyak 40 siswa semester genap tahun ajaran 2017/2018. Sampel dalam penelitian ini yang terdiri dari kelas XI IPA-1 sebanyak 20 siswa sebagai kelas eksperimen dan XI IPA-2 sebanyak 20 siswa sebagai kelas kontrol. Teknik pengumpulan data meliputi kegiatan observasi, evaluasi atau tes dan kegiatan validasi terhadap instrumen yang akan digunakan. Adapun intrument yang digunakan yaitu lembar observasi, lembar tes, dan lembar validasi. Pengambilan data dapat dilakukan dengan beberapa cara yaitu dengan memberikan soal pretes dan posttes. Selanjutnya dilakukan pengolahan data menggunakan uji statistic terhadap hasil data pretes, posttes dari kelas eksperimen dan kelas kontrol.Untuk menguji hipotesis dilakukan analisis statistic pengujian kesamaan dua rata-rata antara kelompok eksperimen dan kelompok control setelah sebelumnya dilakukan pengujian normalitas data dan homogenitas.Dapat ditentukan rata-rata skor dan deviasi standarnya sebagai berikut: Menghitung rerata skor pretes, postest . Menghitung deviasi standar skor pretes, postes . Menguji normalitas data skor pretest postes digunakan uji kecocokan (Chi Kuadrat) . Menguji homogenitas varians skor pretest, postest. Jika sebaran data normal dan homogen, dilanjutkan uji signifikansi dengan statistik uji t. Perhitungan skor pretes dan posttes diperoleh masing-masing kelas eksperimen dan kelas kontrol. Peningkatan kompetensi yang terjadi sebelum dan sesudah pembelajaran dihitung dengan rumus (Surapranata, 2014:50).

Langkah-langkah pengujian yang ditempuh untuk data pretes, posttes adalah sebagai berikut:

a. Uji Normalitas

Uji normalitas dilakukan untuk mengetahui apakah data kedua kelas berasal dari populasi yang berdistribusi normal.

b. Uji Homogenitas

Uji homogenitas dilakukan untuk mengetahui apakah data yang diperoleh memiliki varians yang homogen atau tidak. Uji homogenitas dilakukan untuk mengetahui apakah variansi populasi data yang diuji memiliki variansi yang homogen atau tidak.

c. Uji T Independent Sample T Tes

Uji T dimaksudkan untuk menguji perbedaan rata-rata secara signifikan antara kelas eksperimen dan kelas kontrol setelah diberi perlakuan Ketentuan dalam uji hipotesis menggunakan uji T Independent Sample T Test sebagai berikut:

Ho $: m_{1}=m_{2}$. Hi $: m_{1} \neq m_{2}$. Signifikan $5 \%$. Daerah kritis Ho ditolak jika Sig. (2tailed < 0,05). Statistik Uji. Nilai Sig. (2-tailed). Kesimpulan Jika Sig. (2-tailed) < 
0,05, maka Ho ditolak, dan Hi diterima sebagai jawaban hipotesis.. Perhitungan statistik menggunakan program statistik SPSS 16.0.

\section{Hasil dan Pembahasan}

Hasil penelitian akan dibahas secara sistematis sebagai berikut:

\section{1) Data Nilai Kelompok Eksperimen}

Pada hasil evaluasi tes diawal sebelum kelompok eksperimen diberikan perlakuan (treatment) diperoleh hasil test awal ditampilkan pada Tabel 1.

Tabel 1.

Nilai dan Skor Kelas Eksperimen

\begin{tabular}{rcc}
\hline \multicolumn{1}{l}{ Kelas Interval } & Frekuensi Absolut & Frekuensi Relatif (\%) \\
\hline $80-90$ & 10 & 50 \\
\hline $60-70$ & 6 & 30 \\
\hline $40-50$ & 4 & 8 \\
\hline $20-30$ & - & - \\
\hline 10 & - & - \\
\hline JumlahSiswa & 20 & 100 \\
\hline Jumlah & 1380 & \\
\hline Rata-Rata & 69 & \\
\hline
\end{tabular}

Berdasarkan tabel diatas dapat dilihat bahwa yang mendapatkan nilai siswa tertinggi $80-90$ hanya 50\% siswa, yang mendapat nilai $60-70$ hanya 30\% siswa.

\section{2) Data Nilai Kelompok Kontrol}

Pada hasil evaluasi tes diawal sebelum kelompok kontrol diberikan perlakuan (treatment) diperoleh hasil test awal ditampilkan pada Tabel 2.

Tabel 2.

Nilai dan Skor Kelas Eksperimen

\begin{tabular}{rcc}
\hline Kelas Interval & Frekuensi Absolut & Frekuensi Relatif (\%) \\
\hline $75-85$ & - & - \\
\hline $65-75$ & 5 & 29 \\
\hline $55-65$ & 10 & 58 \\
\hline $45-55$ & 2 & 11 \\
\hline $40-45$ & - & - \\
\hline JumlahSiswa & 17 & \\
\hline Jumlah & 1045 & \\
\hline Rata-Rata & 61 & \\
\hline
\end{tabular}

Berdasarkan tabel diatas dapat dilihat bahwa yang mendapatkan nilai siswa tertinggi berada pada interval 65-75 yaitu 5 siswa atau 29\% siswa. Sementara yang memiliki nilai interval 55-65 sebanyak 10 siswa tahu $58 \%$ siswa. 


\section{3) Uji Normalitas}

Uji normalitas menggunakan uji Kolmogorov-Smirnov dilakukan pada data keaktifan dan pengetahuan siswa kelas XI IPA ${ }^{1}$ dan XI IPA2SMA Negeri 6 Darul Makmur. Interpretasi uji Kolmogorov-Smirnov dengan menggunakan SPSS 16.0 adalah bahwa jika nilai signifikansinya lebih dari 0.05 maka distribusi data dinyatakan memenuhi asumsi normalitas, dan jika nilainya kurang dari $\mathbf{0 . 0 5}$ maka diinterpretasikan sebagai tidak normal. Hasil uji Normalitas diuraikan pada Tabel 3.

Tabel 3.

Uji Normalitas

\begin{tabular}{llll}
\hline & & NILAI $^{\mathbf{a}}$ \\
\hline & & KELAS_XI & \\
\hline $\begin{array}{l}\text { Kolmogrov- } \\
\text { Smirnov }\end{array}$ & EKSPERIMENN H & KONTROL I \\
\hline & Statistic & 69 & 61 \\
\hline & Df & 20 & 20 \\
\hline & Sig. & .072 & .008 \\
\hline
\end{tabular}

Dari tabel 3 diperoleh nilai Asymp.Sig. pada kelas XI IPA ${ }^{1}$ sebagai kelas eksperimen sebesar 0.072, dan pada kelas XI IPA² sebagai kelas kontrol sebesar 0.008. Sehingga keduanya dapat disimpulkan memiliki signifikansi lebih dari 0.05 yang artinya kedua variable tersebut berdistribusi normal.

\section{4) Uji Homogenitas Data}

Uji homogenitas antara kelas XI IPA ${ }^{1}$ sebagai kelas eksperimen dengan kelas XI $\mathrm{IPA}^{2}$ sebagai kelas kontrol menggunakan uji $\mathrm{F}$. program komputer SPSS for Windows dengan ketentuan jika sig. > 0,05 maka data tersebut homogen. Apabila homogenitas terpenuhi maka peneliti dapat melakukan tahap analisa lanjutan.

$\mathrm{H}_{\mathrm{o}}$ : Variansi kedua kelompok homogen

$\mathrm{H}_{1}$ : Variansi kedua kelompok adalah tidak homogen

Dengan menggunakan taraf signifikansi $5 \%$ atau 0.05 , jika signifikansinya yang diperoleh lebih dari 0.05 , maka terima $\mathrm{H}_{\mathrm{o}}$ yang artinya variansi setiap sampel sama (homogen). Dan jika signifikansinya yang diperoleh kurang dari 0.05 , maka tolak $\mathrm{H}_{\mathrm{o}}$ yang artinya variansi setiap sampel tidak sama (tidak homogen).

Tabel 4.

Uji Homogenitas

\begin{tabular}{llll}
\hline \multicolumn{3}{l}{ Test of homogenitas of variances } \\
NILAI & & \\
\hline Levene Statistic & Df1 & Df2 & Sig. \\
\hline 0.08 & 20 & 20 & .080 \\
\hline
\end{tabular}

Diperoleh nilai signifikansinya sebesar 0.080 . Sehingga dapat disimpulkan menerima $\mathrm{H}_{\mathrm{o}}$ yang artinya variansi kedua kelompok adalah homogen.

$$
\mathrm{Ho}>\mathrm{Hi}=\text { (varians data homogen })
$$


$\mathrm{Hi}<H o=$ (varians data tidak homogen)

\section{5) Uji Hipotesis}

Diuji signifikansinya dengan menggunakan analisis uji beda teknis t-test. Sesuai dengan tujuan peneliti yaitu untuk menelitipengaruh multimedia interaktif pada materi jaringan tumbuhan terhadap keaktifan dan pengetahuan, karena jumlah sampel $n_{1}=n_{2}=40$ dan varians homogens $\left(\sigma_{1}^{2}=\sigma_{2}^{2}\right)$ maka dapat menggunakan rumus t-test, baik untuk separed atau polledvarians.

Dari data perhitungan nilai hasil belajar siswa (post test) dapat terlihat bahwa kelas eksperimen (diterapkan penerapan multimedia interaktif pada materi jaringan tumbuhan terhadap keaktifan danpengetahuansiswa) memiliki rata-rata (mean) 69. Sedangkan pada kelas kontrol (tidak diterapkan penerapan multimedia interaktif pada materi jaringan tumbuhan terhadap keaktifan danpengetahuansiswa) memiliki rata-rata (mean) 61 . kriteria uji beda t-test akan memberikan kesimpulan ada beda atau ada pengaruh jika signifikansinya kurang dari atau sama dengan 0.05 .

Tabel 5 .

Uji Analisis signifikansi Uji T-test

\begin{tabular}{|c|c|c|c|c|}
\hline \multicolumn{5}{|c|}{ Independent Samples Test } \\
\hline & & & \multicolumn{2}{|c|}{ NILAI } \\
\hline & & & $\begin{array}{c}\text { Equal } \\
\text { variances } \\
\text { assumed }\end{array}$ & $\begin{array}{c}\text { Equal } \\
\text { variances not } \\
\text { assumed }\end{array}$ \\
\hline \multirow{2}{*}{$\begin{array}{l}\text { Levene's Test for } \\
\text { Equality of Variances }\end{array}$} & \multicolumn{2}{|l|}{$\mathrm{F}$} & \multicolumn{2}{|l|}{3.117} \\
\hline & \multicolumn{2}{|l|}{ Sig. } & \multicolumn{2}{|c|}{.083} \\
\hline \multirow{7}{*}{$\begin{array}{l}\text { t-test for Equality of } \\
\text { Means }\end{array}$} & \multicolumn{2}{|l|}{$\mathrm{T}$} & 4.655 & 4.655 \\
\hline & \multicolumn{2}{|l|}{$\overline{D f}$} & 40 & 52.284 \\
\hline & \multicolumn{2}{|l|}{ Sig. (2-tailed) } & .000 & .000 \\
\hline & \multicolumn{2}{|l|}{ Mean Difference } & 10.806 & 10.806 \\
\hline & \multicolumn{2}{|c|}{ Std. Error Difference } & 2.322 & 2.322 \\
\hline & \multirow{2}{*}{$\begin{array}{l}95 \% \text { Confidence } \\
\text { Interval of the } \\
\text { Difference }\end{array}$} & Lower & 6.162 & 6.148 \\
\hline & & Upper & 15.451 & 15.465 \\
\hline
\end{tabular}

Diperoleh nilai signifikansi sebesar $0.000 \leqslant 0.05$, maka perhitungan SPSS 16 memberikan kesimpulan ada perbedaan atau pengaruh multimedia interaktif pada materi jaringan tumbuhan terhadap keaktifan danpengetahuansiswa antara siswa yang diajar menggunakan penerapan multimedia interaktif dengan siswa yang diajar dengan tidak menggunakan penerapan multimedia interaktif. Sehingga dapat disimpulkan bahwa ada pengaruh yang positif dan signifikan dari penerapan pengaruh multimedia interaktif pada materi jaringan tumbuhan terhadap keaktifan danpengetahuansiswa kelas XI SMA Negeri 6 Darul Makmur.

Dari analisis diperoleh $t_{\text {hitung }}=0.05<t_{\text {tabel }}=0,083$ maka disimpulkan bahwa hipotesis diterima. Hal ini berarti bahwa tidak terdapat interaksi yang signifikan antara 
penggunaan multimedia interaktif pada materi jaringan tumbuhan terhadap keaktifan dan pengetahuan siswa kelas XI SMA Negeri 6 Darul Makmur.

\section{6) Analisis Peningkatan Keaktifan:Aktifitas Siswa}

Analisis N-gain dilakukan untuk mengetahui pengaruh multimedia interaktif pada materi jaringan tumbuhan terhadap keaktifan dan pengetahuan siswa kelas mana yang lebih baik. Apakah kelas eksperimen yang mendapat penerapan multimedia interaktif terhadap keaktifan dan pengetahuan siswa atau kah kelas kontrol yang mendapatkan pengajaran penerapan multimedia interaktif terhadap keaktifan dan pengetahuan siswa. Berikut ini disajikan rekapitulasi rataan N-gain beserta klasifikasinya (Tabel 6).

Tabel 6.

Rataan Dan Klasifikasi Dan Pengetahuan Siswa

\begin{tabular}{ccc}
\hline Kelas & $\bar{x}$ & Klasifikasi \\
\hline Eksperiman & 0,69 & Tinggi \\
\hline Kontrol & 0,61 & Sedang \\
\hline
\end{tabular}

Berdasarkan tabel 6 terlihat bahwa skor kelas eksperimen lebih besar dibandingkan rataan kelas kontrol. Perbedaan nila iini akan diuj ilebih lanjut dengan menguji hipotesis penelitian, sehingga akan diketahui apakah perbedaan nilai rataan keaktifan dan pengetahuan siswa itu signifikan atau tidak.

Selanjutnya pengujian hipotesis dengan menggunakan uji perbedaan rataanya itu uji $t$. Uji $t$ yang dilakukan adalah uji satu pihak yaitu uji pihak kanan.Taraf signifikansi yang digunakan sebesar $0,05 \mathrm{dan} d k=n_{j}+n_{2}-2$. Berdasarkan hipotesis penelitian diatas, maka hipotesis statistik yang akan diuji adalah:

Ho: Tidak ada pengaruh multimedia interaktif pada materi jaringan tumbuhan terhadap keaktifan dan pengetahuan siswa kelas XI SMA Negeri 6 Darul Makmur $\left(\mu_{1=} \mu_{2}\right)$.

$\mathrm{H}_{1}$ : Ada pengaruh multimedia interaktif pada materi jaringan tumbuhan terhadap keaktifan danpengetahuan siswa kelas XI SMA Negeri 6 Darul Makmur $\left(\mu_{1>} \mu_{2}\right)$ Hasil perhitungan uji perbedaan rataan (uji t) skor disajikan dalam Tabel 7.

Tabel 7.

Uji perbedaan rerata skor keaktifan dan pengetahuan siswa

\begin{tabular}{ccccccc}
\hline Kelas & $\bar{x}$ & $\mathrm{~S}$ & thiung & Sig(2-tailed) & Sig(1-tailed) & Kesimpulan \\
\cline { 1 - 3 } Eksperimen & 0,69 & 0,14 & 8,037 & 0,001 & 0,0005 & Hoditolak \\
\cline { 1 - 3 } Kontrol & 0,61 & 0,12 & & & & \\
\hline
\end{tabular}

Terlihat nilai signifikansi(1-tailed) lebih kecil dari 0,05, sehingga $\mathrm{H}_{0}$ ditolak dan $\mathrm{H}_{1}$ diterima. Artinya perbedaan pengaruh multimedia interaktif pada materi jaringan tumbuhan terhadap keaktifan dan pengetahuan siswa.Jadi dapat disimpulkan bahwa penerapan multimedia interaktif pada materi jaringan tumbuhan mempengaruhi keaktifan dan pengetahuan siswa kelas XI SMA Negeri 6 Darul Makmur. 
Berdasarkan hasil analisis mean tes untuk kelompok eksperimen dan control diketahui bahwa hasil tes kelompok eksperimen-kontrol adalah $69 \geq 61$. Dapat disimpulkan bahwa antara kelompok mean control dan mean eksperimen pada akhir nilai atau tes ada perbedaanya itu sebesar 8 . Dengan demikian terdapat pengaruh yang positif dari variable bebas terhadap variable terikat yaitu pengaruh multimedia interaktif terhadap keaktifan dan pengetahuan siswa.

Hasil yang diperoleh memperlihatkan bahwa penggunaan multimedia interaktif mempengaruhi keaktifan dan pengetahuan siswa pada pembelajaran biologi. Hal ini sesuai dengan hasil penelitian relevan bahwa mulimedia interaktif sebagai media pembelajaran berpengaruh terhadap hasil belajar kognitif siswa (Havis, 2018). Hasil yang sama juga ditunjukkan pada penelitian media interaktif dapat meningkatkan hasil belajar dan melatih ketrampilan berpikir kritis siswa kelas XI IPA SMA N 1 batu Sopang (Belajar et al., 2015). Penelitian lain menunjukkan bahwa ada pengaruh penggunaan multimedia interaktif berbasis macromedia flash 8 terhadap keaktifan siswa dan hasil belajar biologi pada materi sistem saraf siswa kelas XI SMA PPMI Assalaam Sukoharjo (Wulandari, 2017).

Kajian lain menunjukkan hasil bahwa dengan penerapan media pembelajran di publish dalam bentuk apk. Dan media akhir dalam bentuk file dan compact disk diperoleh hasil sangat baik 85,83\% setelah diujikan ke siswa SMA N 5 Kota Jambi (Fatmala \& Yelianti, 2016). Kajian lain menunjukkan peningkatan keterampilan berpikir kritis antara kelas konvensional-inkuiri sebesar 16,4\%, kelas konvensional-inkuiri multimedia sebesar 24,6\% dan kelas inkuiri-inkuiri multimedia sebesar 4,15\% (Retnosari et al., 2016). Selanjutnya penerapan mltimedia pada materi sistem saraf pada siswa SMA ditemukan bahwa terdapat perbedaan hasil belajar siswa yang menggunakan multimedia interaktif dengan buku teks. Selain itu, pembelajaran multimedia interaktif juga mampu meningkatkan hasil belajar siswa dibandingkan dengan uyang belajar menggunakan buku teks(Kurniawan, 2019). Pada mahasiswa calon guru juga dibuktikan bahwa pembelajaran berbasisi multimedia interaktif dapat meningkatkan penguasaan konsep mahasiswa calon guru biologi pada topik katabolisme karbohidrat (Rahmatan et al., 2013).

\section{Kesimpulan}

Pengaruh multimedia interaktif pada materi jaringan tumbuhan terhadap keaktifan dan pengetahuan siswa kelas XI SMA Negeri 6 Darul Makmur secara signifikan lebih baik dari pada siswa yang mendapatkan penerapan multimedia interaktif(kriteria $\left.t_{\text {hitung }} \leq t_{\text {tabel }}\right)$. Hal ini ditunjukkan oleh hasil uji T-Test nilai $t_{\text {hitung }}=0,83$, dengan $\mathrm{db}=40$ pada taraf signifikansi $5 \%$ diperoleh $t_{\text {tabel }}=0,005$. Dengan demikian hipotesis pada penelitian ini diterima yang menyatakan bahwa ada pengaruh yang signifikan terhadap keaktifan dan pengetahuan siswa kelas XI SMA Negeri 6 Darul Makmur. Dalam proses pembelajaran keaktifan siswa pada kelas eksperiment meunjukkan interaksi dan bersemangat untuk memahami pembelajaran. Sedangkan siswa di kelas kontrol teramati bahwa keaktifan siswa tidak bersemangat dan tidak termotivasi untuk berinteraksi.

\section{Ucapan Terimakasih (Acknowledgment)}

Terimakasih kepada Mahasiswa Pendidikan Biologi STKIP Bina Bangsa Meulaboh dalam keterlibatan dalam penelitian sebagai tim lapangan. 


\section{Daftar Pustaka}

Aulia, N. W., \& Aina, M. (2016). Pengembangan Multimedia Interaktif Menggunakan Camtasia Studio 8 Pada Pembelajaran Biolog Biologi Materi Kultur Jaringan Untuk SMA Kelas XI MIA. Pendidikan Biologi, 2(1), 20-26.

Belajar, H., Melatihkan Keterampilan, D., Kritis, B., Syahdiani, S., Kardi, S., \& Made Sanjaya, I. G. (2015). Pengembangan Multimedia Interaktif Berbasis Inkuiri Pada Materi Sistem Reproduksi Manusia Untuk Meningkatkan. Berbasis Inkuiri Pada..., 5(1), 727-741.

Fatmala, D., \& Yelianti, U. (2016). Pengembangan Media Pembelajaran Multimedia Interaktif Berbasis Android Pada Materi Plantae Untuk Siswa Sma Menggunakan Eclipse Galileo Development of Learning Media As Interactif Multimedia Based Android on Plantae Material for Senior High School in Using. Biodik, 2(1), 1-6.

Havis, F. dan. (2018). JEMG ; JURNAL EcoMent Global. 3, 183-197.

Kurniawan, G. E. (2019). Jurnal mangifera edu. 3, 62-71.

Rahmatan, H., Liliasari, \& Redjeki, S. (2013). Pembelajaran berbasis multimedia interaktif pada topik katabolisme karbohidrat untuk meningkatkan penguasaan konsep mahasiswa calon guru biologi. Jurnal Pendidikan IPA Indonesia, 2(1), 1-7. https:// doi.org/10.15294/jpii.v2i1.2502

Retnosari, N., Susilo, H., \& Suwono, H. (2016). Pengaruh Model Pembelajaran Inkuiri Terbimbing Berbantuan Multimedia Interaktif Terhadap Berpikir Kritis Siswa Kelas Xi Sma Negeri Di Bojonegoro. Jurnal Pendidikan - Teori, Penelitian, Dan Pengembangan, 1(8), 1529-1535. https://doi.org/10.17977/jp.v1i8.6635

Triyanti, M. (2015). Pengembangan Multimedia Interaktif pada Materi Sistem Saraf untuk Meningkatkan Motivasi dan Hasil Belajar Siswa SMA Kelas XI. Jurnal Bioedukatika, 3(2), 9. https:// doi.org/10.26555/ bioedukatika.v3i2.4148

Wulandari, E. (2017). Penerapan multimedia interaktif berbasis macromedia flash 8 terhadap keaktifan dan hasil belajar biologi materi sistem saraf manusia pada siswa kelas XI SMA PPMI Assalaam Sukoharjo tahun pelajaran 2016/2017. 1-82. 